\title{
KEMAMPUAN APARAT PEMERINTAH DESA DAN EFEKTIVITAS PENGELOLAAN KEUANGAN DESA
}

\section{Rural Government Officials Capability and the Effectiveness of Village Financial Management}

\author{
Yunianingrum $^{1)}$ dan Lala M. Kolopaking ${ }^{1)}$ \\ ${ }^{1)}$ Departemen Sains Komunikasi dan Pengembangan Masyarakat, Fakultas Ekologi Manusia, \\ Institut Pertanian Bogor, Darmaga Bogor 16680, Indonesia \\ E-mail: yunianingrum97@gmail.com; lalako@apps.ipb.ac.id
}

\begin{abstract}
The capability of rural government officials have an important role in the effectiveness of village financial management. This research's objectives are to analyze the capability of rural government officials, to analyze the effectiveness of village financial management and to analyze the relationship between rural government officials' capability to the effectiveness of village financial management in two villages, Bringinwareng village and Guyangan village. The results show that there is a diversity of capabilities of rural government officials. Bringinwareng village (good financial management) has a good officials capability compared to Guyangan village (poor financial management) that has the capability of officials at a moderate level. The level of effectiveness of financial management of Bringinwareng village is better, because transparency, accountability, participation, and ratios of village financial effectiveness tend to be high. In contrast to Guyangan village which has moderate effectiveness due to low transparency, moderate accountability and participation, but has a high ratio of village financial effectiveness. Based on the results of research that has been tested statistically shows that there is a correlation between the capability of rural government officials with the effectiveness of village financial management, both in Bringinwareng village and Guyangan village.
\end{abstract}

Keywords: rural government officials, capability, village financial management

\begin{abstract}
ABSTRAK
Kemampuan aparat pemerintah desa memiliki perananan penting dalam keefektifan pengelolaan keuangan desa. Penelitian ini bertujuan untuk menganalisis kemampuan aparat pemerintah desa, menganalisis keefektifan pengelolaan keuangan desa dan menganalisis hubungan kemampuan aparat pemerintah desa terhadap efektivitas pengelolaan keuangan desa di dua desa, yaitu Desa Bringinwareng dan Desa Guyangan. Hasil penelitian menunjukkan ada keragaman kemampuan aparat pemerintah desa. Desa Bringinwareng (pengelolaan keuangan baik) memiliki kemampuan aparat yang baik dibandingkan Desa Guyangan (pengelolaan keuangan kurang baik) yang memiliki kemampuan aparat pada tingkat sedang. Tingkat efektivitas pengelolaan keuangan Desa Bringinwareng lebih baik, karena transparansi, akuntabilitas, partisipatif, dan rasio efektivitas keuangan desa cenderung tinggi. Berbeda dengan Desa Guyangan yang memiliki efektivitas sedang karena transparansi yang rendah, akuntabilitas dan partisipatif yang sedang, tetapi memiliki rasio efektivitas keuangan desa yang tinggi. Berdasarkan hasil penelitian yang telah diuji secara statistik menunjukkan bahwa terdapat hubungan antara kemampuan aparat pemerintah dengan efektivitas pengelolaan keuangan desa, baik di Desa Bringinwareng maupun di Desa Guyangan.
\end{abstract}

Kata kunci: aparat pemerintah desa, kemampuan, pengelolaan keuangan desa

\section{PENDAHULUAN}

Desa adalah tolok ukur pertama dalam melihat kemajuan suatu negara. Seringkali desa terbaikan oleh negara dan penyelenggaraan desa hanya terbatas pada perintah pemerintah pusat ataupun daerah. Adanya Undang-Undang No. 6 Tahun 2014 tentang Desa mulai memperlihatkan bahwa pemerintah telah memberikan perhatiannya kepada desa. Pemberian kewenangan pada desa juga memiliki arti bahwa seluruh penyelenggaraan pemerintah desa dilaksanakan oleh desa secara 
mandiri, sehingga dibutuhkan sinergi antar pemerintah desa ${ }^{1}$ dalam pengelolannya.

Selain itu melalui undang-undang desa ini pula digulirkan dana desa dengan jumlah yang berbeda dengan peraturan tahun-tahun sebelumnya. Peraturan Pemerintah (PP) No. 60 Tahun 2014 tentang Dana Desa menjelaskan bahwa pengalokasian dana desa dihitung berdasarkan jumlah desa dan dialokasikan dengan memperhatikan jumlah penduduk, angka kemiskinan, luas wilayah dan tingkat kesulitan geografis. Bergulirnya dana desa ini memang menjadi modal besar bagi desa untuk mengoptimalkan potensi dan menyejahterakan masyarakat, tetapi juga tantangan bagi pemerintah desa dalam pengelolaan keuangan desa serta pertanggungjawaban yang sesuai dengan undangundang yang berlaku.

Pemerintah desa sebagai penyelenggara pemerintahan terdepan dalam pelaksanaan keuangan desa, maka diperlukan adanya kapasitas perangkat desa yang memadai. Wasistiono dan Tahir (2006) mengemukakan bahwa umumnya pemerintah desa memiliki kelemahan-kelemahan dalam hal berikut; (1) kualitas sumber daya manusia yang menjadi aparat desa masih rendah; (2) kebijakan atau peraturan-peraturan terkait pemerintahan desa masih belum sempurna; (3) kemampuan dalam hal perencanaan pembangunan di tingkat desa masih rendah; (4) terbatasnya sarana dan prasanana yang dapat menunjang operasional administrasi desa. Kelemahan ini merupakan suatu keterbatasan yang dapat mengganggu efisiensi dan efektivitas dalam pelaksanaan pekerjaan. Selain itu, dapat pula menurunkan motivasi aparat desa sehingga pada akhirnya akan menghambat pencapaian tujuan pemerintah desa

Kecamatan Winong merupakan salah satu kecamatan yang berada di Kabupaten Pati yang terdiri dari 30 Desa yang penyelenggaraan pemerintahannya dilaksanakan oleh pemerintah desa. Diantara 30 desa tersebut, dipilih 2 desa yang berbeda dalam pengelolaan keuangan desanya. Terdapat desa dengan kategori baik dan kurang baik dalam pengelolaan keuangan desa. Desa dengan

\footnotetext{
${ }^{1}$ Pemerintah Desa adalah Kepala Desa atau yang disebut dengan nama lain dibantu perangkat desa sebagai unsur penyelenggara Pemerintahan Desa.
}

kategori baik adalah Desa Bringinwareng, sedangkan desa dengan kategori kurang baik adalah Desa Guyangan. Pemerintah desa adalah penyelenggara pemerintahan desa yang sesuai dengan Undang-Undang yang berlaku, sehingga membutuhkan kemampuan yang memadai. Oleh karena itu, menjadi penting dalam mengkaji hubungan antara kemampuan aparat pemerintah desa dengan efektivitas pengelolaan keuangan desa.

Rumusan masalah dalam penelitian ini adalah (1) Bagaimana kemampuan aparat pemerintah desa dalam mengelola keuangan desa? ; (2) Bagaimana efektivitas dalam pengelolaan keuangan desa? ; (3) Bagaimana hubungan kemampuan aparat pemerintah desa dengan efektivitas pengelolaan keuangan desa?

Tujuan dalam penelitian ini adalah (1) Menganalisis kemampuan aparat pemerintah desa dalam mengelola keuangan desa; (2) Menganalisis efektivitas pengelolaan keuangan desa; (3) Menganalisis hubungan antara kemampuan aparat pemerintah desa terhadap efektivitas pengelolaan keuangan desa.

\section{PENDEKATAN TEORITIS}

Pemerintah desa merupakan unsur penyelenggara pemerintahan desa yang terdiri dari kepala desa dan perangkat desa sebagai unsur pembantu. Pemerintah desa sebagai suatu organisasi harus memperhatikan sumber daya manusia (SDM), karena SDM mempunyai peranan yang penting. Kepala desa dan perangkat desa yang merupakan bagian dari organisasi pemerintah desa yang membutuhkan kemampuan yang memadai dalam menjalankan tugasnya agar sesuai dengan tujuan pemerintah desa. Kemampuan menurut Hersey dan Blanchard (1986) menyatakan bahwa kemampuan kerja merupakan sebuah kondisi pada seseorang agar dapat berdaya guna dan berhasil dalam melaksanakan pekerjaan sesuai bidangnya.

Berdasarkan definisi tersebut, kemampuan aparat pemerintah desa dalam pembangunan akan diukur menurut konsep Hersey dan Blanchard (1986). Terdapat 3 (tiga) kemampuan yang harus dimiliki 
aparat pemerintah desa dalam melaksanakan tugasnya, yaitu:

1. Kemampuan teknis

Kemampuan dalam menggunakan pengetahuan, metode, teknis dan peralatan yang diperlukan untuk melaksanakan pekerjaan tertentu yang diperoleh dari pengalaman, pendidikan dan pelatihan. Aparat pemerintah desa harus memiliki kemampuan teknis yang memadai, karena dalam konsep ini kemampuan teknis merupakan kemampuan yang paling mendasar yang harus dimiliki oleh pekerja.

2. Kemampuan sosial

Kemampuan untuk berinteraksi secara efektif kepada orang-orang dan memberikan dukungan individu pada organisasi. Kemampuan sosial yang harus dimiliki oleh aparat pemerintah desa tidak hanya sebatas pada organisasi pemerintahannya namun juga kepada masyarakat.

3. Kemampuan konseptual

Kemampuan dalam memahami kompleksitas organisasi secara menyeluruh. Kemampuan ini juga didefinisikan sebagai kemampuan dalam menganalisis suatu permasalahan yang terjadi. Berdasarkan konsep ini, kemampuan konseptual merupakan kemampuan tertinggi yang biasanya dimiliki oleh seorang pemimpin dalam hal ini adalah kepala desa, namun tidak menutup kemungkinan desa dengan sumber daya aparat yang baik memiliki aparatnya kemampuan konseptual yang baik.

Penyelenggaraan pemerintahan desa salah satunya adalah dalam pengelolaan keuangan desa. Keuangan selalu berkaitan dengan beberapa penyelewengan dana, sehingga perlu untuk mengetahui realisasi dana atau keuangan dari suatu kegiatan atau program. Ukuran tersebut dapat diketahui melalui efektivitasnya pengelolannya. Efektivitas pengelolaan keuangan desa dapat diukur melalui penerapan asas-asas pengelolaan keuangan desa, yaitu transparan, akuntabel, partisipatif dan rasio efektivitas. Rasio efektivitas sebagaimana dalam penelitian Yuniarti (2015) digunakan untuk menggambarkan kemampuan aparat pemerintah desa melalui data APBDesa, yaitu kemampuan aparat pemerintah desa dalam merealisasikan pendapatan asli desa dibandingkan dengan target yang ditetapkan. Kriteria rasio efektivitas didasarkan pada Kemendagri No. 690.900.327. Oleh karena itu, berdasarkan definisi yang telah diungkapkan sebelumnya, efektivitas pengelolaan keuangan desa adalah keuangan desa yang dikelola dengan hasil sesuai dengan sasaran atau tujuan yang telah ditetapkan sebelumnya.

\section{Kerangka Pemikiran}

Kerangka penelitian ini menjelaskan menjelaskan dugaan penulis tentang hubungan kemampuan aparat pemerintah desa dengan efektivitas pengelolaan keuangan desa. Besarnya dana yang digulirkan pemerintah dari APBN di era ini merupakan sebuah tantangan bagi pemerintah desa untuk mengelolanya dengan baik. Pengelolaan tersebut dibutuhkan kesiapan serta kemampuan. Berdasarkan penelitianpenelitian sebelumnya yaitu oleh Asrori (2014) telah diketahui kemampuan atau kapasitas pemerintah desa dalam penyelenggaraan pemerintahan desa, yaitu kemampuan pemerintah desa dalam manajemen keuangan desa. Terdapat pula penelitian mengenai efektivitas APBDesa oleh Yuniarti (2015). Kemudian Harits (2004) menyatakan bahwa efektivitas organisasi bergantung kepada kemampuan pejabat struktural, sehingga penulis mencoba menduga hubungan kemampuan aparat pemerintah desa dengan efektivitas pengelolaan keuangan desa.

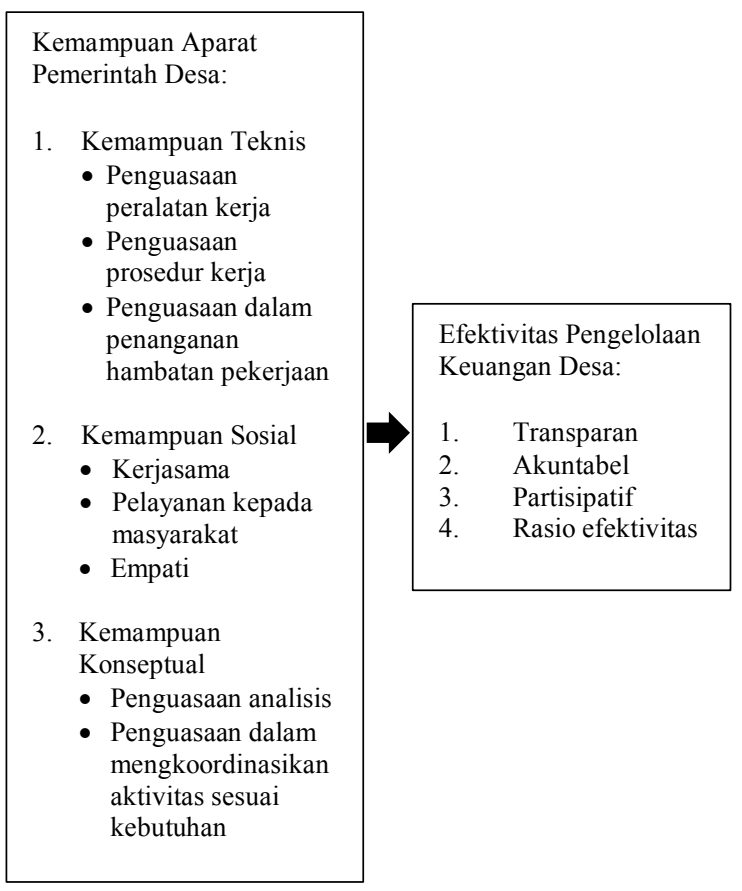




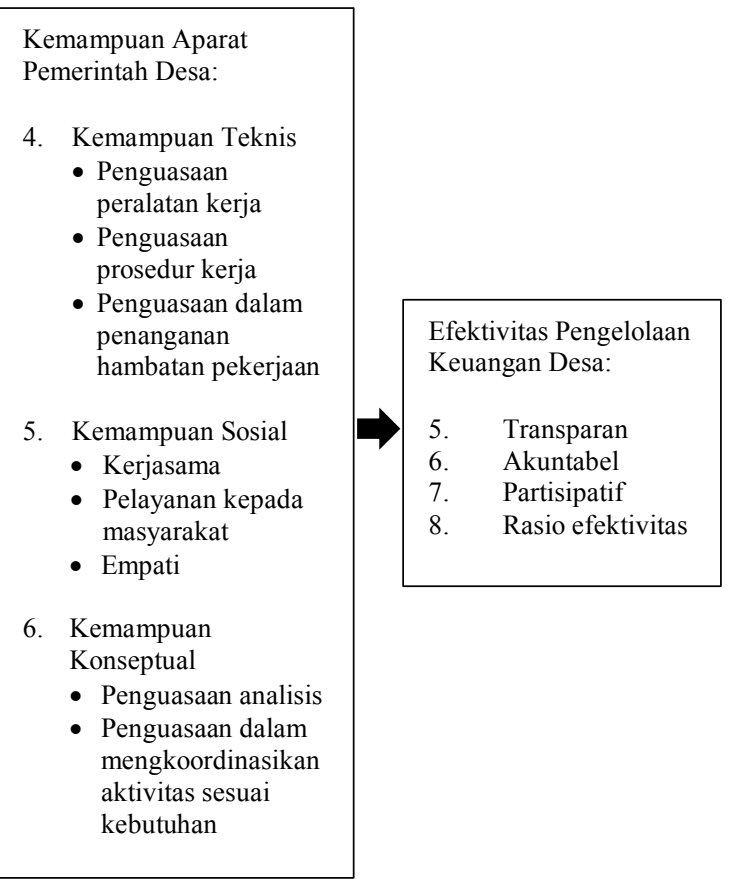

Keterangan

$\Rightarrow \quad$ : hubungan

Gambar 1 Kerangka pemikiran

Konsep Kemampuan yang digunakan dalam penelitian ini adalah Kemampuan menurut Hersey dan Blanchard (1986), kemampuan kerja adalah keadaan yang ada pada diri pekerja yang secara sungguh-sungguh berdaya guna dan berhasil dalam bekerja sesuai bidang pekerjaannya yang diukur dengan tiga indikator yaitu; (1) kemampuan teknis; (2) kemampuan sosial; (3) kemampuan konseptual.

Kemampuan aparat pemerintah desa selalu dikaitkan dengan baik, buruk dan atau efektif tidaknya suatu pengelolaan keuangan desa. Pengukuran efektivitas pengelolaan keuangan desa menggunakan asas-asas pengelolaan keuanan desa Permendagri No. 113 Tahun 2014 tentang Pengelolaan Keuangan Desa, yaitu transparan, akuntabel, partisipatif. Kemudian efektivitas pengelolaan keuangan desa ini juga diukur dari rasio efektivitas Kemendagri No. 690.900.327 Tahun 1996 tentang Pedoman Penilaian dan Kinerja Keuangan.

\section{METODE PENELITIAN}

Penelitian ini menggunakan metode kuantitatif yang dilengkapi dengan data kualitatif. Metode kuantitatif dilakukan dengan teknik purposive, yaitu pengambilan responden dari suatu populasi secara sengaja. Penelitian dilakukan mulai dari bulan Oktober 2016 sampai dengan Juli 2017 di Desa Bringinwareng dan Desa Guyangan, Kecamatan Winong, Kabupaten Pati, Jawa Tengah. Lokasi dipilih dengan kategori yang berbeda, yaitu desa dengan pengelolaan yang baik dan buruk. Desa tersebut adalah Desa Bringinwareng (baik) dan Desa Guyangan(buruk). Penilaian pengelolaan keuangan desa ini didapatkan dari Kecamatan Winong.

Responden dalam penelitian ini adalah 30 orang dari Desa Bringinwareng dan 30 orang dari Desa Guyangan masyarakat yang menghadiri musrenbangdes karena dianggap lebih mengetahui tentang pengelolaan keuangan desa. Pengolahan data dilakukan dengan aplikasi Microsoft Excel 2010 dan IBM SPSS Statistics 16.0 for Windows. Analisis hubungan antarvariabel dilakukan dengan uji korelasi Rank Spearman. Uji korelasi ersebut untuk menganalisis hubungan kemampuan aparat pemerintah desa dan pengelolaan keuangan desa.

\section{HASIL DAN PEMBAHASAN}

\section{Gambaran Umum Desa Bringinwareng dan Desa Guyangan}

Secara geografis, Desa Bringinwareng lebih dekat dengan kabupaten sehingga dapat disebut desa dengan orientasi kota, sedangkan Desa Guyangan berada di ujung kecamatan yang merupakan kawasan hutan negara dengan daerah yang lebih tinggi dibanding desa lain. Hal ini menyebabkan Desa Guyangan berada jauh dari titik-titik pusat. Kondisi lain, yaitu demografis menunjukkan Desa Bringinwareng mempunyai jumlah penduduk yang lebih sedikit dibandingkan Desa Guyangan. Jumlah penduduk Desa Guyangan yang cukup besar ini didukung dengan luasan desa yang lebih besar pula.

Kondisi sosial ekonomi juga dipengaruhi dari lingkungan. Kecamatan Winong mempunyai potensi padi sawah sehingga seluruh desa yang ada di kecamatan inipun mempunyai sawah. Hal inilah yang menjadi alasan bahwa dikedua desa ini sebagian besar penduduknya bermata pencaharian sebagai petani pada sawah. 
Tabel 1 Data umur, tingkat pendidikan, dan lama menjabat aparat pemerintah Desa Bringinwareng

\begin{tabular}{|c|c|c|c|c|}
\hline No & Jabatan & $\begin{array}{l}\text { Umur } \\
\text { (tahun) }\end{array}$ & $\begin{array}{l}\text { Tingkat } \\
\text { pendidikan }\end{array}$ & $\begin{array}{l}\text { Lama } \\
\text { menjabat } \\
\text { (tahun) }\end{array}$ \\
\hline 1. & Kepala desa & 47 & SMA & 3 \\
\hline 2. & Sekretaris desa & 44 & S1 & 24 \\
\hline 3. & $\begin{array}{l}\text { Kaur } \\
\text { admnistrasi dan } \\
\text { umum }\end{array}$ & 31 & SMA & 0,5 \\
\hline 4. & $\begin{array}{l}\text { Staf kaur } \\
\text { admnistrasi dan } \\
\text { umum }\end{array}$ & 29 & S1 & 0,5 \\
\hline 5. & Kaur keuangan & 38 & SMA & 7 \\
\hline 6. & $\begin{array}{l}\text { Staf kaur } \\
\text { keuangan }\end{array}$ & 28 & SMA & 0,5 \\
\hline 7. & $\begin{array}{l}\text { Kasi } \\
\text { Pemerintahan }\end{array}$ & 38 & SMA & 8 \\
\hline 8. & $\begin{array}{l}\text { Kasi } \\
\text { Pembangunan }\end{array}$ & 50 & SMP & 30 \\
\hline 9. & $\begin{array}{l}\text { Kasi } \\
\text { Kesejahteraan } \\
\text { rakyat }\end{array}$ & 26 & SMA & 0,5 \\
\hline 10. & Kepala dusun & & (tidak ada) & \\
\hline
\end{tabular}

Terdapat perbedaan antara aparat Desa Bringinwareng dengan Desa Guyangan dari segi umur dan pendidikan. Aparat Desa Bringinwareng cenderung proporsional dalam umur, artinya terdapat aparat dengan usia muda dari umur 26 hingga tua, sedangkan aparat Desa Guyangan cenderung diatas 33 tahun. Begitu pula dalam hal latar belakang pendidikan aparat desa. Sebesar 22,3\% aparat Desa Bringinwareng adalah seorang sarjana, hanya $11,2 \%$ yang berpendidikan SMP dan sisanya berpendidikan SMA. Data ini ditemukan berbeda di Desa Guyangan bahwa sebesar 33,4\% berpendidikan SMP. Jumlah tersebut tentu lebih besar dibanding Desa Bringinwareng. Latar belakang pendidikan ini dianggap sebagai salah satu yang mempengaruhi dalam mengelola desa. Contohnya adalah dalam hal mengelola keuangan desa.

Terdapat penilaian dari kecamatan dalam hal pengelolaan keuangan desa. Belum ada evaluasi secara struktural atau secara fungsional untuk menilai desa yang paling baik dalam pengelolaan keuangan desa, namun pihak dari kecamatan telah melakukan penilaian berdasarkan beberapa kriteria. Kriteria pengelolaan keuangan desa yang baik tersebut dilihat dari ketertiban administrasi keuangan desa, kesesuaian pelaksanaan pembangunan dengan RPJMDes, hasil inspektorat, peran serta tim PTPKD, dan peran serta masyarakat. Hasil peniliaian kecamatan ini menunjukkan pengelolaan keuangan desa yang baik adalah Desa Bringinwareng, sedangkan pengelolaan keuangan desa yang buruk adalah Desa Guyangan. Hal inilah yang menjadi dasar dalam penelitian ini untuk membuktikan pengelolaan baik didukung dengan kemampuan yang baik atau sebaliknya.

Tabel 2 Data umur, tingkat pendidikan, dan lama menjabat aparat pemerintah Desa Guyangan

\begin{tabular}{|c|c|c|c|c|}
\hline No & Jabatan & $\begin{array}{l}\text { Umur } \\
\text { (tahun) }\end{array}$ & $\begin{array}{l}\text { Tingkat } \\
\text { pendidikan }\end{array}$ & $\begin{array}{l}\text { Lama } \\
\text { menjabat } \\
\text { (tahun) }\end{array}$ \\
\hline 1. & Kepala desa & 57 & SMP & 6 \\
\hline 2. & Sekretaris desa & 57 & SMA & 29 \\
\hline 3. & $\begin{array}{l}\text { Kaur } \\
\text { admnistrasi dan } \\
\text { umum }\end{array}$ & 36 & SMA & 0,17 \\
\hline 4. & $\begin{array}{l}\text { Staf kaur } \\
\text { admnistrasi dan } \\
\text { umum }\end{array}$ & & (tidak ada) & \\
\hline 5. & Kaur keuangan & 45 & SMP & 16 \\
\hline 6. & $\begin{array}{l}\text { Staf kaur } \\
\text { keuangan }\end{array}$ & 33 & SMA & 0,17 \\
\hline 7. & $\begin{array}{l}\text { Kasi } \\
\text { Pemerintahan }\end{array}$ & 58 & SMP & 29 \\
\hline 8. & $\begin{array}{l}\text { Kasi } \\
\text { Pembangunan }\end{array}$ & 47 & SMA & 16 \\
\hline 9. & $\begin{array}{l}\text { Kasi } \\
\text { Kesejahteraan } \\
\text { rakyat }\end{array}$ & 48 & SMA & 17 \\
\hline 10. & Kepala dusun & 42 & SMA & 14 \\
\hline
\end{tabular}

\section{Kemampuan Teknis Aparat Pemerintah Desa}

Pemerintah desa sebagai penyelenggara pemerintahan desa haruslah mempunyai kemampuan yang memadai dalam melaksanakan tugasnya. Salah satu kemampuan yang harus dikuasai adalah kemampuan teknis. Kemampuan teknis adalah kemampuan aparat pemerintah desa dalam menggunakaan pengetahuan, metode, teknis, dan peralatan yang diperoleh dari pengalaman, pendidikan, dan pelatihan untuk melaksanakan tugas dan fungsi sesuai jabatannya. Kemampuan teknis dilihat dari penguasaan terhadap peralatan kerja, penguasaan prosedur kerja, dan penguasaan dalam menangani hambatan pekerjaannya.

Desa Bringinwareng merupakan desa yang memiliki kemampuan pengelolaan keuangan desa yang baik berdasarkan data penilaian Kecamatan Winong, sedangkan Desa Guyangan mendapatkan penilaian 
yang buruk. Hal tersebut kemudian dibuktikan dengan hasil penelitian ini.

Tabel 3 Jumlah dan persentase pendapat responden tentang kemampuan teknis aparat pemerintah Desa Bringinwareng dan Desa Guyangan

\begin{tabular}{lcccc}
\hline \multirow{2}{*}{$\begin{array}{c}\text { Pendapat } \\
\text { responden } \\
\text { terhadap } \\
\text { kemampuan } \\
\text { teknis aparat }\end{array}$} & $\mathrm{n}$ & $\%$ & $\mathrm{n}$ & $\%$ \\
\cline { 2 - 5 } $\begin{array}{c}\text { Desa } \\
\text { Bringinwareng }\end{array}$ & $\begin{array}{c}\text { Desa } \\
\text { Guyangan }\end{array}$ \\
\cline { 2 - 5 } pemerintah desa & & 0 & 17 & 56,7 \\
Buruk & 0 & 20 & 13 & 43,3 \\
Sedang & 6 & 80 & 0 & 0 \\
Baik & 24 & 100 & 30 & 100 \\
\hline Total & 30 & &
\end{tabular}

Tabel 3 ini menyajikan perbedaan kemampuan teknis yang dimiliki aparat pemerintah kedua desa. Sejumlah 24 repsonden Desa Bringinwareng atau sebesar $80 \%$ menilai bahwa kemampuan teknis aparat pemerintah Desa Bringinwareng baik, sedangkan hanya 6 responden lainnya atau 20\% yang menilai sedang. Hal tersebut dikuatkan oleh pendapat pendamping desa yang ada di Kecamatan Winong. Sebagai seorang pendamping desa, telah mengetahui kemampuan aparat pemerintah desa dari 30 desa yang ada di Kecamatan Winong. Aparat pemerintah Desa Bringinwareng dinyatakan mempunyai kemampuan teknis yang paling baik diantara seluruh desa di Kecamatan Winong, karena kualifikasi SDM, kemampuan IT, dan penggalaman yang dimiliki.

Berbeda dengan Desa Bringinwareng, sejumlah 17 responden Desa Guyangan atau 56,7\% menilai bahwa kemampuan teknis aparat pemerintah Desa Guyangan buruk sedangkan 13 responden lainnya atau 43,3\% menilai sedang. Hal tersebut berarti kemampuan teknis aparat pemerintah Desa Guyangan cenderung buruk. Hasil ini sesuai dengan hasil data kuantitatif bahwa penguasaan peralatan kerja, penguasaan prosedur kerja dan penguasaan dalam penanganan hambatan pekerjaan aparat pemerintah Desa Guyangan juga pada kategori buruk. Aparat pemerintah Desa Guyangan yang dominan tidak muda lagi dengan kemampuan teknis yang terbatas juga tidak mampu lagi untuk belajar secara teknis, mengingat bahwa penyelenggaraan pemerintahan desa membutuhkan kemampuan komputer sehingga penting untuk dikuasai aparat desa.

\section{Kemampuan Sosial Aparat Pemerintah Desa}

Kemampuan sosial adalah kemampuan aparat pemerintah desa untuk berinteraksi secara efektif kepada sesama aparat pemerintah desa maupun kepada masyarakat. Aparat pemerintah desa sebagai penyelenggara pemerintah desa tentunya lebih sering berinteraksi dengan masyarakat, sehingga harus mempunyai kemampuan sosial yang baik. Seorang aparat pemerintah desa juga harus mempunyai kemampuan sosial yang memadai untuk menjalin komunikasi dengan sesama aparat pemerintah desa baik dari satu desa maupun dengan desa yang lain. Kondisi kemampuan sosial yang memadai ini harus terpenuhi agar organisasi pemerintahan desa dapat mencapai visi misi yang diinginkan oleh desa. Kemampuan sosial aparat pemerintah desa dilihat dari pendapat responden terhadap kerjasama antarpemerintah desa, pelayanan kepada masyarakat dan empati aparat pemerintah desa.

Tabel 4 Jumlah dan persentase pendapat responden tentang kemampuan sosial aparat pemerintah Desa Bringinwareng dan Desa Guyangan

\begin{tabular}{lcccc}
\hline Pendapat responden & \multicolumn{3}{c}{ Responden } \\
\cline { 2 - 5 } $\begin{array}{c}\text { tentang kemampuan } \\
\text { sosial aparat }\end{array}$ & \multicolumn{2}{c}{$\begin{array}{c}\text { Desa } \\
\text { Bringinwareng }\end{array}$} & \multicolumn{2}{c}{ Desa } \\
Gemerintah desa & $\mathrm{n}$ & $\%$ & $\mathrm{n}$ & $\%$ \\
\cline { 2 - 5 } \multicolumn{1}{c}{ pemgan } \\
\hline Buruk & 0 & 0 & 0 & 0 \\
Sedang & 8 & 26,7 & 30 & 100 \\
Baik & 22 & 73,3 & 0 & 0 \\
\hline Total & 30 & 100 & 30 & 100 \\
\hline
\end{tabular}

Berdasarkan Tabel 4, pendapat responden Desa Bringinwareng terhadap kemampuan sosial aparat pemerintah Desa Bringinwareng cenderung baik. Hal tersebut terlihat pada tabel bahwa, sejumlah 22 responden atau $73,3 \%$ menilai bahwa kemampuan sosial aparat pemerintah Desa Bringinwareng baik, sedangkan 8 responden lainnya atau 26,7\% menilai sedang. Pendapat tentang kemampuan sosial aparat pemerintah Desa Bringinwareng yang cenderung baik ini karena kemampuan aparat pemeritah Bringinwareng dalam menjalin hubungan dengan sesama aparat dan masyarakat. Sesama aparat pemerintah desa menjalin hubungan kerjasama didalam maupun diluar jam kerja. Begitu pula dengan hubungan ke masyarakat. Masyarakat 
merasa baik atas segala bentuk pelayanan dari aparat pemerintah desa.

Hasil penelitian kemampuan sosial aparat pemerintah Desa Guyangan berbeda dengan Desa Bringinwareng. Seluruh responden atau 100\% menilai bahwa kemampuan sosial aparat pemerintah Desa Guyangan dalam kategori sedang. Temuan di lapang menyatakan, kemampuan sosial dalam kerjasama antar aparat desa masyarakat cenderung kurang karena adanya permasalahan internal, sedangkan pada pelayanan kepada masyarakat menunjukkan bahwa masyarakat merasa pelayanan sudah baik. Kemampuan sosial dalam berempati di antara aparat juga kurang dikarenakan adanya permasalahan internal tersebut. Hal ini mempunyai arti kemampuan sosial, aparat pemerintah Desa Bringinwareng mempunyai kemampuan sosial yang baik, sedangkan aparat pemerintah Desa Guyangan mempunyai kemampuan sosial yang sedang.

\section{Kemampuan Konseptual Aparat Pemerintah Desa}

Kemampuan konseptual adalah penguasaan aparat pemerintah desa dalam memahami kompleksitas pemerintahan desa. Kemampuan konseptual dilihat dari penguasaan analisis dan penguasaan dalam mengoordinasikan aktivitas sesuai kebutuhan. Kemampuan konseptual dalam sebuah organisasi biasanya dimiliki oleh seorang pemimpin, dalam sebuah desa pemimpin tersebut berarti kepala desa. Kepala desa dengan tugas dan fungsinya sebagai penyelenggara serta penanggung jawab dari program yang ada di desa yang dapat mengkoordinasikan seluruh program dengan baik. Hal ini tidak menutup kemungkinan bahwa sebagai perangkat desa juga dapat mempunyai kemampuan konseptual yang baik. Kemampuan konseptual yang dimiliki perangkat desa berguna dalam menganalisis segala situasi bahkan mengoordinasikan segala aktivitas pemerintahan desa dengan baik, sehingga tidak bergantung pada pemimpin atau kepala desa.

Hasil penelitian kemampuan konseptual aparat pemerintah Desa Bringinwareng sama seperti pada hasil kemampuan teknis dan sosial yaitu dominan baik. Dapat dilihat bahwa sejumlah 23 responden atau $76,7 \%$ menilai kemampuan konseptual aparat pemerintah Desa Bringinwareng baik, sedangkan 7 lainnya atau 23,3\% sedang. Hasil yang baik dikarenakan kepala desa maupun perangkat desa dapat melakukan analisis dengan baik, namun memiliki kekurangan yaitu tidak semua perangkat desa mampu menilai hasil pekerjaan aparat lain. Hal tersebut berarti penguasaan analisis yang cukup baik, sedangkan penguasaan dalam mengoordinasikan aktivitas juga baik karena semua aparat desa dapat melakukan semua aktivitas tugas dan fungsinya tanpa perintah terlebih dahulu.

Tabel 5 Jumlah dan persentase pendapat responden tentang kemampuan konseptual aparat pemerintah Desa Bringinwareng dan Desa Guyangan

\begin{tabular}{|c|c|c|c|c|}
\hline \multirow{2}{*}{$\begin{array}{c}\text { Pendapat responden } \\
\text { tentang kemampuan } \\
\text { konseptual aparat } \\
\text { pemerintah desa }\end{array}$} & \multicolumn{2}{|c|}{$\begin{array}{c}\text { Desa } \\
\text { Bringinwareng }\end{array}$} & \multicolumn{2}{|c|}{$\begin{array}{c}\text { Desa } \\
\text { Guyangan }\end{array}$} \\
\hline & $\mathrm{n}$ & $\%$ & $\mathrm{n}$ & $\%$ \\
\hline Buruk & 0 & 0 & 19 & 63,3 \\
\hline Sedang & 7 & 23,3 & 11 & 36,7 \\
\hline Baik & 23 & 76,7 & 0 & 0 \\
\hline Total & 30 & 100 & 30 & 100 \\
\hline
\end{tabular}

Hasil pada Desa Bringinwareng tersebut berbeda dengan Desa Guyangan. Terlihat pada tabel 5, sejumlah 19 responden taau $63,3 \%$ menilai kemampuan konseptual aparat pemerintah Desa Guyangan buruk, sedangkan 11 responden lainnya atau $36,7 \%$ menyatakan sedang. Hal tersebut berarti kemampuan konseptual aparat pemerintah Desa Guyangan berdasarkan pendapat responden cenderung buruk. Hal tersebut dikarenakan kurangnya kemampuan analisis perangkat desa dan kurangnya pengoordinasian aktivitas yang baik diantara aparat pemerintah Desa Guyangan. Hampir dari semua tugas menyangkut seluruh program diambil alih oleh kepala desa tanpa mengikutsertakan perangkat desa sehingga koordinasi aktivitas diantara aparatnya kurang.

\section{Efektivitas Pengelolaan Keuangan Desa}

\section{Transparansi}

Salah satu unsur dalam pengelolaan keuangan desa yang baik adalah dengan adanya transparansi. Transparansi adalah keterbukaan aparat pemerintah desa kepada masyarakat sehingga memungkinkan masyarakat untuk mengetahui dan akses terhadap informasi keuangan desa. Pemerintah desa dalam melakukan transparansi pengelolaan keuangan desa berarti harus mengungkapkan hal-hal yang sifatnya material secara berkala kepada pihak-pihak yang memiliki kepentingan dalam hal ini yaitu masyarakat luas. 
Tabel 6 Jumlah dan persentase pendapat responden terhadap transparansi pengelolaan keuangan desa

\begin{tabular}{|c|c|c|c|c|}
\hline \multirow{3}{*}{$\begin{array}{l}\text { Pendapat responden } \\
\text { tentang transparansi } \\
\text { pengelolaan } \\
\text { keuangan desa }\end{array}$} & \multicolumn{4}{|c|}{ Responden } \\
\hline & \multicolumn{2}{|c|}{$\begin{array}{c}\text { Desa } \\
\text { Bringinwareng }\end{array}$} & \multicolumn{2}{|c|}{$\begin{array}{c}\text { Desa } \\
\text { Guyangan }\end{array}$} \\
\hline & $\mathrm{n}$ & $\%$ & $\mathrm{n}$ & $\%$ \\
\hline Rendah & 0 & 0 & 17 & 56,7 \\
\hline Sedang & 1 & 3,3 & 11 & 36,6 \\
\hline Tinggi & 29 & 96,7 & 2 & 6,7 \\
\hline Total & 30 & 100 & 30 & 100 \\
\hline
\end{tabular}

Berdasarkan Tabel 6 tersebut 29 responden Desa Bringinwareng atau 96,7\% menilai bahwa transparansi pengelolaan keuangan desa tinggi, sedangkan hanya 1 responden atau $3,3 \%$ yang menyatakan pengelolaan keuangan desa di Desa Bringinwareng dalam kategori sedang. Berdasarkan penilaian masyarakat, masyarakat cenderung menilai aparat pemerintah Desa Bringinwareng saat ini sangat terbuka kepada masyarakat. Setiap anggaran yang masuk baik dari pemerintah maupun dari yang lain selalu di informasikan dan dilaporkan secara terbuka kepada masyarakat. Selama kepemimpinan kepala desa saat ini (Mashudi) setiap tahun anggaran, pemerintah Desa Bringinwareng juga selalu menempelkan laporan pertanggungjawaban APBDesa di papan informasi desa. Papan informasi tersebut tersedia di depan balai desa dan dibeberapa pojok RW yang dapat diakses oleh masyarakat. Oleh karena itu, masyarakat merasa mudah jika ingin mengetahui keuangan desa.

Desa Guyangan cenderung memiliki penilaian yang rendah dalam hal transparansi keuangan desa. Sejumlah 17 responden atau 56,7\% menyatakan transparansi pengelolaan keuangan Desa Guyangan rendah, sedangkan 11 responden atau $36,6 \%$ menyatakan sedang, dan hanya 2 responden atau $6,7 \%$ yang menyatakan tinggi. Transparansi yang kurang ini terlihat pada kosongnya papan informasi desa, sehingga masyarakat umum tidak tahu tentang keuangan desa, bahkan beberapa perangkatpun kurang mengetahui tentang pengelolaan keuangan desa.

Masyarakat juga menganggap bahwa dalam pengelolaan keuangan desa aparat pemerintah Desa Guyangan kurang transparan. Program-program dilaksanakan dan diketahui secara fisik, namun perincian anggaran yang digunakan pada setiap program tidak dipublikasikan dengan baik. Laporan pertanggungjawaban atau segala sesuatu mengenai keuangan desa tidak dipublikasikan dengan baik terlihat pada kosongnya papan informasi desa yang terletak di dalam kantor desa.

\section{Akuntabilitas}

Tata kelola pemerintahan yang baik salah satunya tercermin dari akuntabilitas. Akuntabiitas aparat pemerintah desa dalam pengelolaan keuangan desa yaitu perwujudan pertanggungjawaban dari setiap kegiatan dalam mencapai tujuan yang ditetapkan. Pemerintah desa harus bertanggung jawab terhadap pelaksanaan tugas dan wewenangnya dalam pengelolaan keuangan desa. Akuntabilitas pengelolaan keuangan desa ini dinilai dari adanya pelaporan pertanggungjawaban, akses publik terhadap laporan pertanggungjawaban tersebut, penjelasan terhadap tindakan yang menjadi tanggung jawab dari pemerintah desa dalam mengelola keuangan desa, penjelasan penggunaan keuangan desa di musyawarah desa dan adanya pengawasan oleh pemerintah desa serta masyarakat.

Indikator akuntabilitas tersebut kemudian dinilai oleh masyarakat yang menjadi responden. Hasil penelitian akuntabilitas pengelolaan keungan desa pada Desa Bringinwareng dan Desa Guyangan disajikan dalam tabel berikut:

Tabel 7 Jumlah dan persentase pendapat responden terhadap akuntabilitas pengelolaan keuangan desa

\begin{tabular}{llclc}
\hline $\begin{array}{c}\text { Pendapat responden } \\
\text { tentang akuntabilitas } \\
\begin{array}{c}\text { pengelolaan } \\
\text { keuangan desa }\end{array}\end{array}$ & \multicolumn{2}{c}{$\begin{array}{c}\text { Desa } \\
\text { Bringinwareng }\end{array}$} & \multicolumn{2}{c}{$\begin{array}{c}\text { Desa } \\
\text { Guyangan }\end{array}$} \\
\cline { 2 - 5 } & $\mathrm{n}$ & $\%$ & $\mathrm{n}$ & $\%$ \\
\hline Rendah & 0 & 0 & 12 & 40 \\
Sedang & 3 & 10 & 18 & 60 \\
Tinggi & 27 & 90 & 0 & 0 \\
\hline Total & 30 & 100 & 30 & 100 \\
\hline
\end{tabular}

Berdasarkan Tabel 7 tersebut, dapat dilihat bahwa pendapat responden terhadap akuntabilitas keuangan Desa Bringinwareng dominan tinggi. Sejumlah 27 responden atau $90 \%$ menyatakan tinggi, sedangkan hanya 3 responden atau $10 \%$ yang menyatakan sedang. Aparat pemerintah Desa Bringinwareng dinilai sangat bertanggung jawab dalam menggunakan uang desa. Segala bentuk kegiatan pengelolaan keuangan desa dilaksanakan menurut rancangan dan dilaksanakan bersama tim pelaksana keuangan desa yang dibentuk, sehingga terdapat pembagian tugas dan tanggungjawab yang jelas 
dalam mengelola keuangan desa. Begitu pula dalam pelaksanaan juga dilakukan sesuai dengan tanggung jawabnya masing-masing. BPD sebagai wakil dari masyarakat meninjau langsung tindakan pelaksanakan yang menggunakan keuangan desa, begitu pula masyarakat turut mengawasi programprogram yang ada disekitar mereka. Perihal laporan pertanggungjawaban, aparat pemerintah desa melaporkannya setiap akhir tahun anggaran dalam musrenbangdes yang dihadiri pula oleh masyarakat.

Hasil pada Desa Guyangan adalah sejumlah 18 responden atau $60 \%$ menyatakan akuntabilitas sedang, sedangkan 12 responden lainnya atau $40 \%$ menyatakan akuntabilitasnya rendah, sehingga akuntabilitas cenderung pada kategori sedang. Masyarakat cenderung menilai akuntabilitas dari pertanggungjawaban. Laporan dinilai baik dan disampaikan setiap akhir tahun anggaran bersamaan dengan musrenbangdes, tetapi selain pada saat musrenbangdesa tidak ada yang bisa akses laporan pertanggungjawaban tersebut kecuali kepala desa dan bendahara desa. Sehingga perangkat apalagi masyarakat kurang akses dalam laporan pertanggungjawaban tersebut. Begitu pula dalam pembagian tugas dan tanggung jawab dalam pengelolaan keuangan desa. Sebuah tim pelaksana pengelolaan keuangan desa seperti yang tercantum pada undang-undang desa telah dibentuk, namun dalam pelaksanaannya tim tersebut tidak digunakan. Artinya dalam pelaksanaan tidak sesuai dengan tugas dan tanggung jawab masing-masing, namun setiap program dilaksanakan dengan baik. Penggunaan keuangan desa juga disampaikan dalam musyawarah desa, namun pengawasan dalam penggunaan uang desa tersebut tidak banyak yang mengetahui.

\section{Partisipatif}

Pengelolaan keuangan desa membutuhkan kontribusi dari beberapa pihak, bukan hanya pemerintah desa tetapi juga lembaga-lembaga terkait dan juga masyarakat. Oleh karena itu dalam mengelola keuangan desa harus partisipatif, yaitu mengikutsertakan masyarakat dan kelembagaan desa dalam pengelolaan keuangan desa. Masyarakat bukan hanya target dari pembangunan yang menggunakan keuangan desa, tetapi juga sebagai pengelola keuangan desa itu sendiri. Pengelolaan keuangan desa yang partisipatif ini dilihat dari proaktif pemerintah desa dalam mendorong masyarakat untuk ikut berpartisipasi, mempertimbangkan aspirasi masyarakat dalam musyawarah desa, dan mengikutsertakan masyarakat dalam pengambilan keputusan.

Tabel 8 Jumlah dan persentase pendapat responden terhadap partisipasi masyarakat dalam pengelolaan keuangan desa

\begin{tabular}{|c|c|c|c|c|}
\hline \multirow{3}{*}{$\begin{array}{l}\text { Pendapat responden } \\
\text { tentang partisipasi } \\
\text { masyarakat dalam } \\
\text { pengelolaan } \\
\text { keuangan desa }\end{array}$} & \multicolumn{4}{|c|}{ Responden } \\
\hline & \multicolumn{2}{|c|}{$\begin{array}{c}\text { Desa } \\
\text { Bringinwareng }\end{array}$} & \multicolumn{2}{|c|}{$\begin{array}{c}\text { Desa } \\
\text { Guyangan }\end{array}$} \\
\hline & $\mathrm{n}$ & $\%$ & $\mathrm{n}$ & $\%$ \\
\hline Rendah & 0 & 0 & 11 & 36,7 \\
\hline Sedang & 1 & 3,3 & 15 & 50 \\
\hline Tinggi & 29 & 96,7 & 4 & 13,3 \\
\hline Total & 30 & 100 & 30 & 100 \\
\hline
\end{tabular}

Berdasarkan Tabel 8, 29 responden atau 96,7\% menyatakan pengelolaan keuangan desa di Bringinwareng partisipatifnya tinggi, sedangkan hanya 1 responden saja atau 3,3\% yang menyatakan sedang, artinya aparat pemerintah Desa Bringinwareng dalam mengelola keuangan desa sudah partisipatif. Setiap pengadaan musyawarah, kepala desa melalui perangkatnya mengundang seluruh masyarakat untuk ikut hadir dan berpendapat dalam musyawarah. Undangan ke masyarakat biasanya disampaikan melalui pengumuman di RT atau RW. Musyawarah yang dilakukan di Desa Bringinwareng tidak hanya musrenbangdes, tetapi setiap ada hal baru atau permasalahan langsung dimusyawarahkan.

Berdasarkan data dan temuan di lapang, masyarakat Desa Bringinwareng secara umum mengakui bahwa dalam pengelolaan keuangan desa, aparat pemerintah Desa Bringinwareng selalu berusaha mengikutsertakan masyarakat. Pengikutsertaan ini dalam berbagai tahap, mulai dari perencanaan, pelaksanaan, pengawasan sampai dengan menyampaikan secara rinci segala bentuk program yang menggunakan uang desa. Berbeda dengan hasil data yang diperoleh di Desa Guyangan. Hanya 4 responden di Desa Guyangan atau 13,3\% yang menyatakan partisipasi masyarakat tinggi, sedangkan 15 responden atau 50\% menyatakan sedang, dan 11 responen lainnya atau 36,7 menyatakan rendah. Temuan di lapang menyatakan bahwa aparat pemerintah desa mengundang dari pihak masyarakat untuk ikut serta dalam musyawarah desa, tetapi hanya orang-orang tertentu saja yang berani mengusulkan program atau kegiatan yang dibutuhkan masyarakat. Terdapat dominasi pihak-pihak tertentu dalam pengambilan keputusan 
musrenbang. Masyarakat tidak sepenuhnya berpartisipasi aktif dalam musyawarah desa, hanya menghadiri namun kurang dalam memberikan aspirasi pembangunan untuk desa.

\section{Rasio Efektivitas}

Efektivitas dalam pengelolaan keuangan desa pada dasarnya dilihat dari pencapaian tujuan atau target keuangan desa. Efektivitas merupakan hubungan antara keluaran dengan tujuan atau sasaran yang harus dicapai. Efektivitas ini diukur Kemendagri No. 690.900.327 yaitu menggunakan rasio efektivitas. Pengukuran tingkat efektivitas keuangan desa diketahui melalui rasio antara realisasi Pendapatan Asli Desa (PADesa) dengan target PADesa. Berdasarkan data sekunder berupa APBDesa tahun anggaran 2015 di Desa Bringinwareng dan Desa Guyangan, maka hasil rasio efektivitas pengelolaan keuangan desa dapat dilihat sebagai berikut.

Tabel 9 Rasio efektivitas keuangan Desa Bringinwareng dan Desa Guyangan tahun 2015

\begin{tabular}{llccc}
\hline \multicolumn{1}{c}{ Desa } & $\begin{array}{c}\text { Target } \\
\text { PADesa }\end{array}$ & $\begin{array}{c}\text { Realisasi } \\
\text { PADesa }\end{array}$ & $\begin{array}{c}\text { Rasio } \\
(\%)\end{array}$ \\
\hline 1. & Bringinwareng & 145.600 .000 & 145.600 .000 & 100 \\
2. Guyangan & 207.600 .000 & 207.600 .000 & 100 \\
\hline
\end{tabular}

Berdasarkan perhitungan rasio efektivitas tersebut maka aparat pemerintah Desa Bringinwareng termasuk dalam kategori sangat efektif. Pendapatan asli desa yang cukup besar yang berasal dari tanah kas desa ini telah digunakan untuk pembangunan beberapa infrastruktur desa, yang kemudian sisanya digunakan untuk lapangan desa. Hal ini mempunyai arti bahwa aparat pemerintah Desa Bringinwareng dalam melaksanakan pembangunan atau pemerintahan desa pada tahun 2015 telah tersumbang cukup besar dari pendapatan asli desa, namun untuk tahun anggaran berikutnya akan bergantung kepada pendapatan yang diperoleh dari kelompok transfer dan kelompok pendapatan lain.

Berdasarkan hasil pada rasio efektivitas diatas pula, maka dapat diketahui bahwa rasio efektivitas pengelolaan keuangan Desa Guyangan $100 \%$, yang berarti sangat efektif. Pendapatan asli desa menurut aparat desa maupun masyarakat selalu diartikan dengan tanah kas desa yang merupakan bagian dari hasil usaha desa. Tanah kas desa milik Desa Guyangan ini pada tahun anggaran sampai tahun 2015 dan tahun-tahun sebelumnya di sewakan kepada swasta. Tanah ini disewa pertahun perHa, dan biasanya disewa oleh perusahaan gula, sehingga tanah kas desa tersebut ditanami tebu. Tetapi tanah tersebut telah sebagian besar telah dijual dan digunakan untuk pembangunan gorong-gorong, sumbangan pembangunan masjid, pengkulitan TPQ dan beberapa pembangunan fisik lain. Kemudian sisa dari tanah kas desa yang dijual tersebut digunakan untuk menambah lapangan desa yang dianggap kurang luas. Berdasarkan hasil tersebut maka Desa Guyangan hingga tahun anggaran 2015 ini masih dapat mengandalkan tanah kas desa atau 'bondo desa' sebagai pendapatan asli desa, namun demikian pada tahun anggaran selanjutnya akan bergantung pada pendapatan transfer dan lain-lain.

\section{Hubungan Kemampuan Aparat Pemerintah Desa dengan Efektivitas Pengelolaan Keuangan Desa}

Salah satu tujuan dalam penelitian ini adalah untuk menjawab hipotesis uji dengan menguji hipotesis menggunakan uji korelasi rank spearman. Hipotesis dalam penelitian ini, yaitu diduga terdapat hubungan antara kemampuan aparat pemerintah desa dengan efektivitas pengelolaan keuangan desa. Uji korelasi akan dilakukan dengan tabulasi silang dan diuji menggunakan uji korelasi rank spearman untuk mengetahui kuatnya hubungan antara kedua variabel tersebut. Hasil uji rank spearman kemudian menunjukkan koefisien korelasi yang diinterpretasikan.

Tabel 10Jumlah dan persentase pendapat responden tentang kemampuan aparat pemerintah Desa dengan efektivitas pengelolaan keuangan Desa Bringinwareng

\begin{tabular}{|c|c|c|c|c|c|c|c|c|}
\hline \multirow{3}{*}{$\begin{array}{c}\text { Kemampuan } \\
\text { Aparat } \\
\text { Pemerintah } \\
\text { Desa } \\
\text { Bringinwareng }\end{array}$} & \multicolumn{8}{|c|}{ Efektivitas Pengelolaan Keuangan Desa } \\
\hline & \multicolumn{2}{|c|}{$\begin{array}{l}\text { Ren } \\
\text { dah }\end{array}$} & \multicolumn{2}{|c|}{ Sedang } & \multicolumn{2}{|c|}{ Tinggi } & \multicolumn{2}{|c|}{ Total } \\
\hline & $\mathrm{n}$ & $\%$ & $\mathrm{n}$ & $\%$ & $\mathrm{n}$ & $\%$ & $\mathrm{n}$ & $\%$ \\
\hline Buruk & 0 & 0 & 0 & 0 & 0 & 0 & 0 & 0 \\
\hline Sedang & 0 & 0 & 2 & 100 & 0 & 0 & 2 & 100 \\
\hline Baik & 0 & 0 & 1 & 3,6 & 27 & 96,4 & 28 & 100 \\
\hline Total & 0 & 0 & 3 & 10 & 27 & 90 & 30 & 100 \\
\hline
\end{tabular}

Tabel 10 menunjukkan bahwa kemampuan aparat pemerintah desa dominan sedang memiliki 
efektivitas pengelolaan keuagan desayang sedang pula, hal tersebut ditunjukkan dengan persentase $100 \%$. Hasil dalam pemamparan sebelumnya, kemampuan aparat pemerintah Desa Bringinwareng cenderung tinggi sehingga efektivitas pengelolaan keuangan desanya tinggi pula dinyatakan responden dengan persentase $96,4 \%$. Berdasarkan wawancara mendalam, baik dari masyarakat maupun aparat pemerintah desa setuju bahwa semua aparat pemerintah Desa Bringinwareng sebagai pengelola desa telah menguasai kemampuan teknis, sosial dan konseptual dengan baik. Ketiga kemampuan aparat pemerintah Desa Bringinwareng ini dianggap responden telah memadai dalam mengelola keuangan desa, sehingga menghasilkan pengelolaan keuangan desa yang efektif. Masyarakat menilai bahwa pengelolaan keuangan yang efektif adalah menggunakan seluruh keuangan desa untuk kebutuhan masyarakat disertai dengan musyawarah dan keterbukaan dalam menggunakan.

Setelah mengetahui hasil pada tabulasi silang kemampuan aparat pemerintah Desa Bringinwareng dengan efektivitas pengelolaan keuangan Desa Bringinwareng seperti yang dijelaskan di atas, maka hipotesis dapat diuji. Berdasarkan hasil uji korelasi rank spearman, dapat disimpulkan bahwa variabel kemampuan aparat pemerintah Desa Bringinwareng memiliki hubungan sangat kuat dengan efektivitas pengelolaan keuangan Desa Bringinwareng, yaitu $0,802 * *$ dengan nilai signifikansi $0,000<\rho(0.01)$. Sehingga dapat ditarik kesimpulan bahwa terdapat hubungan antara kemampuan aparat pemerintah Desa Bringinwareng dengan efektivitas pengelolaan keungan Desa Bringinwareng.

Tabel 11 Jumlah dan persentase pendapat responden terhadap kemampuan aparat pemerintah desa dengan efektivitas pengelolaan keuangan Desa Guyangan

\begin{tabular}{|c|c|c|c|c|c|c|c|c|}
\hline \multirow{3}{*}{$\begin{array}{c}\text { Kemampuan } \\
\text { Aparat } \\
\text { Pemerintah } \\
\text { Desa } \\
\text { Guyangan }\end{array}$} & \multicolumn{8}{|c|}{ Efektivitas Pengelolaan Keuangan Desa } \\
\hline & \multicolumn{2}{|c|}{ Rendah } & \multicolumn{2}{|c|}{ Sedang } & \multicolumn{2}{|c|}{ Tinggi } & \multicolumn{2}{|c|}{ Total } \\
\hline & $\mathrm{n}$ & $\%$ & $\mathrm{n}$ & $\%$ & $\mathrm{n}$ & $\%$ & $\mathrm{n}$ & $\%$ \\
\hline Buruk & 12 & 92,3 & 0 & 0 & 1 & 7,7 & 13 & 100 \\
\hline Sedang & 0 & 0 & 16 & 94,1 & 1 & 5,9 & 17 & 100 \\
\hline Baik & 0 & 0 & 0 & 0 & 0 & 0 & 0 & 0 \\
\hline Total & 12 & 40 & 16 & 53,3 & 2 & 6,7 & 30 & 100 \\
\hline
\end{tabular}

Berdasarkan tabel 11, maka kemampuan aparat pemerintah Desa Guyangan cenderung sedang memiliki efektivitas pengelolaan keuangan desa yang sedang, yaitu sebesar $94,1 \%$. Persentase yang cukup besar kedua yaitu 92,3\% menunjukkan ba hwa kemampuan aparat pemerintah desa yang buruk memiliki efektivitas pengelolaan keuangan desa yang rendah pula. Hal ini menunjukkan bahwa dalam tabulasi tersebut terdapat hubungan antara kemampuan aparat pemerintah Desa Guyangan dengan efektivitas pengelolaan keuangan desa, mengingat pada subbab kemampuan dipaparkan bahwa kemampuan aparat pemerintah Desa Guyangan ada pada kategori sedang dan begitu pula dalam efektivitas pengelolaan keuangan desanya.

Setelah mengetahui hasil pada tabulasi silang kemampuan aparat pemerintah Desa Guyangan dengan efektivitas pengelolaan keuangan Desa Guyangan seperti yang dijelaskan di atas, maka hipotesis dapat diuji. Berdasarkan hasil uji korelasi rank spearman, dapat disimpulkan bahwa variabel kemampuan aparat pemerintah Desa Guyangan memiliki hubungan sangat kuat dengan efektivitas pengelolaan keuangan Desa Guyangan, yaitu $0,825^{* *}$ dengan nilai signifikansi $0,000<\rho(0.01)$. Sehingga dapat ditarik kesimpulan bahwa terdapat hubungan antara kemampuan aparat pemerintah Desa Guyangan dengan efektivitas pengelolaan keuangan Desa Guyangan.

\section{SIMPULAN DAN SARAN}

\section{Simpulan}

Berdasarkan uraian di bab-bab sebelumnya, dapat disimpulkan bahwa (1) Terdapat keragaman kemampuan aparat pemerintah desa dalam mengelola keuangan desa. Desa Bringinwareng (pengelolaan keuangan baik) memiliki kemampuan aparat desa yang lebih baik dibandingkan dengan Desa Guyangan (pengelolaan keuangan kurang baik), dengan demikian kapasitas aparat pemerintah Desa Bringinwareng dalam pengelolaan keuangan desa lebih baik dibanding Desa Guyangan. (2) Tingkat efektivitas pengelolaan keuangan desa lebih baik Desa Bringinwareng daripada Desa Guyangan. Efektivitas pengelolaan keuangan desa Desa Bringinwareng yang tinggi karena transparansi akuntabilitas, partisipatif, dan rasio efektivitas keuangan desa cenderung tinggi. Berbeda dengan Desa Guyangan memiliki efektivitas yang sedang karena transparansi yang rendah, akuntabilitas dan partisipatif yang sedang, tetapi memiliki rasio 
efektivitas keuangan desa yang tinggi. (3) Terdapat korelasi yang sangat kuat antara kemampuan aparat pemerintah desa dengan efektivitas pengelolaan keuangan desa, baik di Desa Bringinwareng maupun Desa Guyangan.

\section{Saran}

Berdasarkan hasil penelitian, maka terdapat dua saran yang penulis ajukan sebagai bahan masukan untuk berbagai pihak:

1. Bagi pemerintah Desa :

a. Desa Bringinwareng (baik) masih perlu pelatihan mengingat perkembangan peraturan terkait pengelolaan keuangan desa

b. Desa Guyangan (kurang baik) yang memiliki kemampuan teknis pada tingkat sedang maka diperlukan pelatihan peningkatan kapasitas di bidang teknis untuk meningkatkan pengelolaan keuangan desa. Dibutuhkan pula transparansi pengelolaan keuangan desa yang tinggi dengan melakukan publikasi berbagai tahap pengelolaan keuangan desa di papan pengumuman desa.

2. Bagi akademisi masih memerlukan penelitian lebih lanjut yang dalam untuk mengetahui faktor yang mempengaruhi kemampuan aparat pemerintah desa dan faktor yang mempengaruhi efektivitas dalam pengelolaan keuangan desa.

\section{DAFTAR PUSTAKA}

Adisasmita R. 2006. Membangun Desa Partisipatif. Yogyakarta (ID): Graha Ilmu.

Asrori. 2014. Kapasitas Desa dalam

Penyelenggaran Pemerintahan Desa di Kabupaten Kudus. JBP [Internet]. [diunduh 2016 Maret 26]; 6(2): 101-116. Tersedia pada:

http://ejurnalbpp.com/ojs/index.php/jbp/articl e/view/40/37.

Astuty E dan Fanida E H. 2013. Akuntabilitas Pemerintahan Desa dalam Pengelolaan Anggaran Pendapatan dan Belanja Desa (APBDes) (Studi pada Alokasi Dana Desa Tahun Anggaran 2011 di Desa Sareng kecamatan Geger Kabupaten Madiun ). J Publika [Internet]. [diunduh 2016 Mei 10]; 1(3). Tersedia pada : http://ejournal.unesa.ac.id/index.php/publika/ article/view/2533.

Fadli M, Hamidi J, Lutfi M. 2013. Pembentukan Peraturan Desa Partisipatif (Head To A Good Village Governance). Malang (ID): UB Press.

Gibson JL, Ivancevich JH, Donnelly JH. 1989. Organisasi: Perilaku, Struktur, Proses. Ed ke5. Jakarta (ID): Erlangga.

Harits B. 2004. Paradigma Baru Dimensi-Dimensi Prima Administrator Publik. Bandung (ID): Insani Press.

Hasibuan, Malayu SP. 2005. Manajemen Sumber Daya Manusia. Edisi: Revisi. Jakarta (ID): PT Bumi Aksara.

Hersey P, Blanchard K. 1995. Manajemen Perilaku Organisasi: Pendayagunaan Sumber Daya Manusia. Dharma A, penerjemah. Jakarta (ID): Erlangga.

Kartika RS. 2012. Partisipasi Masyarakat dalam Mengelola Alokasi Dana Desa (ADD) di desa Tegeswetan dan desa jangkrikan Kecamatan Kepil kabupaten Wonosobo. JBP [Internet]. [diunduh 2016 Maret 7]; 4(3). Tersedia pada : http://ejurnalbpp.com/ojs/index.php/jbp/articl e/viewFile/70/67.

Magdalena D, Kusuma AR, Utomo HS. 2013. Implementasi alokasi Dana Desa di Wilayah Kecamatan Tenggarong Seberang Kabupaten Kutai Kartenegara. JAR [Internet]. [diunduh 2016 Mei 7]; 1(3) : 668-679. Tersedia pada : http://ar.mian.fisip-unmul.ac.id/site/wpcontent/uploads/2013/11/jurnal\%20upload\%2 0\%2811-14-13-04-51-00\%29.pdf.

Mardiasmo.2004. Efisiensi dan efektivitas. Jakarta (ID): Andy.

Mardikanto T dan Soebiato P. 2012. Pemberdayaan Masyarakat dalam Perspektif Kebijakan Publik. Bandung ( ID ) : Alfa Beta.Mardiyah S U K. 2006. Optimalisasi Kinerja Pemerintahan Desa. J Efisiensi [Internet]. [diunduh 2016 Mei 10]; 6(2): 159-166. Tersedia pada : 
http://journal.uny.ac.id/index.php/efisiensi/art icle/view/3861.

Menteri Dalam Negeri Republik Indonesia. 2014. Peraturan Menteri Dalam Negeri Republik Indonesia Nomor 113 Tahun 2014 Tentang Pengelolaan Keuangan Desa. [internet]. [diunduh 7 Maret 2016]. Tersedia pada : http://keuangandesa.com/wpcontent/uploads/2015/04/Permendagri-No113-Tahun -2014-Tentang-PengelolaanKeuangan-Desa.pdf.

Noor A. 2007. Ilmu Sosial Dasar. Bandung (ID): Pustaka Setia.

Nurcholis H. 2011. Pertumbuhan dan penyelenggaraan Pemerintahan Desa. Jakarta (ID): Erlangga.

Paramitha LM, Domai T, Suwondo. 2013. Kinerja Aparat Pemerintah Desa dalam Rangka Otonomi Desa ( Studi di Desa Gulun, Kecamatan Maospati, kabupaten Magetan ). JAP [Internet]. [diunduh 2016 April 4]; 1(4): 91-100. Tersedia pada :

http://administrasipublik.studentjournal.ub.ac .id/index.php/jap/article/viewFile/119/104.

$[\mathrm{PP}]$ Peraturan Pemerintah Republik Indonesia. 2014. Peraturan Pemerintah Nomor 43 Tahun 2014 Tentang Peraturan Pelaksanaan UU Nomor 6 Tahun 2014 Tentang Desa. [internet]. [diunduh 7 Maret 2016]. Tersedia pada : https://www.kemenkopmk.go.id/sites/defa ult/files/produkhukum/PP\%20Nomor\%20 43\%20Tahun\%202014.pdf.

[PP] Peraturan Pemerintah Republik Indonesia. 2014. Peraturan Pemerintah Nomor 60 Tahun 2014 Tenang Dana Desa yang Bersumber dari Anggaran Pendapatan dan Belanja Negara. [internet]. [diunduh 7 Maret 2016]. Tersedia pada : http://peraturan.go.id/pp/nomor-60-tahun2014-

11e4bbf0f784ee84a5c5313334373134.html.

[PP] Peraturan Pemerintah Republik Indonesia. 2005. Peraturan Pemerintah Nomor 72 Tahun 2005 Tentang Desa. [internet]. [diunduh 7 Maret 2016]. Tersedia pada:https://www.google.co.id/?gws rd=cr, ss1\&ei=vHqAVo20Gc2OuASs6oqQAg\#q $=$ $\mathrm{pp}+72+\operatorname{tahun}+2005$.
Rahardjo. (1999). Pengantar Sosiologi Pedesaan dan Pertanian. Yogyakarta (ID): Gadjah Mada University Press.

Ramlan Surbakti. (1992). Memahami Ilmu Politik. Jakarta (ID): PT Gramedia Widiasarana IndonesiaThomas . 2013. Pengelolaan Alokasi Dana Desa dalam Upaya Meningkatkan Pembangunan di Desa Sebawang kecamatan Sesayap Kabupaten Tana Tidung. JPI [Internet]. [diunduh 2016 Maret 7]; 1:51-64. Tersedia pada : http://ejournal.pin.or.id/site/wpcontent/uploads/2013/02/jurnal $\% 20$ thomas \%20\%2802-26-13-05-47-11\%29.pdf.

Robbins SP. 2003. Perilaku Organisasi. Jakarta (ID): Indeks.

Rosyida I dan Nasdian FT. 2011. Partisipasi Masyarakat dan Stakeholder dalam Penyelenggaraan Program Corporate Social Responsibility (CSR) dan Dampaknya Terhadap Komunitas Pedesaan. Jurnal Sodality. [Internet]. [diunduh 27 November 2013]. 5(1). Tersedia pada :http://jurnalsodality.ipb.ac.id /jurnalpdf/4\%20Isma\%20Rosyida.pdf.

Sukirno S. 2006. Ekonomi Pembangunan. Edisi Kedua. Jakarta (ID): Kencana Predana Media Group.

Swasto B. 2003. Pengaruh Sumber Daya Manusia ( Pengaruhnya Terhadap Kinerja Karyawan dan Imbalan). Malang (ID): FIA UB.

Syamsi S. 2014. Partisipasi Masyarakat dalam Mengontrol Penggunaan Anggaran Dana Desa. JISIP [Internet]. [diunduh $2016 \mathrm{Mei}$ 29]; 3(1). Tersedia pada :

http://publikasi.unitri.ac.id/index.php/fisip/art icle/view/69/74.

Thoha M. 1998. Perspektif Perilaku Birokrasi, Jakarta (ID): Rajawali Press.

[UU] Undang-Undang Republik Indonesia. 2014. Undang-Undang Nomor 6 Tahun 2014 Tentang Desa. [internet]. [diunduh 7 Maret 2016]. Tersedia pada: http://www.bpn.go.id/Publikasi/PeraturanPerundangan/Undang Undang/undangundang-nomor-6-tahun-2014-4723. 
Wasisitiono S dan Tahir T. 2006. Prospek

Pengembangan Desa. Jatinangor (ID): Fokus Media.

Winardi. 2002. Motivasi dan Pemotivasi dalam Manajemen. Jakarta (ID): Raja. 